\title{
Correction to: Magma chamber stratification of the 1815 Tambora caldera-forming eruption
}

\author{
Indranova Suhendro ${ }^{1} \oplus \cdot$ Atsushi Toramaru $^{1} \cdot$ Tomoharu Miyamoto $^{1} \cdot$ Yasuo Miyabuchi $^{2} \cdot$ Takahiro Yamamoto $^{3}$
}

Published online: 13 October 2021

(c) The Author(s) 2021

\section{Correction to: Bulletin of Volcanology (2021) 83: 63 https://doi.org/10.1007/s00445-021-01484-x}

The article "Magma chamber stratification of the 1815 Tambora caldera-forming eruption", written by Suhendro, I., Toramaru, A., Miyamoto, T., Miyabuchi, Y., and Yamamoto, T., was originally published Online First without Open Access. After publication in volume 83, issue 10, article number 63 the author decided to opt for Open Choice and to make the article an Open Access publication. Therefore, the copyright of the article has been changed to (C) The Authors 2021 and the article is forthwith distributed under the terms of the Creative Commons Attribution 4.0 International License, which permits use, sharing, adaptation, distribution and reproduction in any medium or format, as long as you give appropriate credit to the original author(s) and the source, provide a link to the Creative Commons licence, and indicate if changes were made. The images or other third party material in this article are included in the article's Creative Commons licence, unless indicated otherwise in a credit line to the material. If material is not included in the article's Creative Commons licence and your intended use is not permitted by statutory regulation or exceeds the permitted use, you will need to obtain permission directly from the copyright holder. To view a copy of this licence, visit http://creativecommons.org/licenses/by/4.0.

The original article has been corrected.

Open Access This article is licensed under a Creative Commons Attribution 4.0 International License, which permits use, sharing, adaptation, distribution and reproduction in any medium or format, as long as you give appropriate credit to the original author(s) and the source, provide a link to the Creative Commons licence, and indicate if changes were made. The images or other third party material in this article are included in the article's Creative Commons licence, unless indicated otherwise in a credit line to the material. If material is not included in the article's Creative Commons licence and your intended use is not permitted by statutory regulation or exceeds the permitted use, you will need to obtain permission directly from the copyright holder. To view a copy of this licence, visit http://creativecommons.org/licenses/by/4.0/.
The original article can be found online at https://doi.org/10.1007/ s00445-021-01484-x.

Indranova Suhendro

indranovasuhendro10@gmail.com

1 Department of Earth and Planetary Sciences, Graduate School of Science, Kyushu University, Nishiku, 744, Motooka, Fukuoka 819-0395, Japan

2 Center for Water Cycle, Marine Environment and Disaster Management, Kumamoto University, Kurokami 2-39-1, Chuoku, Kumamoto 860-8555, Japan

3 Geological Survey of Japan, AIST, Higashi 1-1-1 Central 7, Tsukuba 305-5867, Japan 